\title{
Nephroprotective effect of Pleurotus ostreatus extract against cadmium chloride toxicity in rats
}

\author{
MOHAMED A. DKHIL, MARWA S.M. DIAB, MAHA S. LOKMAN, HEBA EL-SAYED, \\ AMIRA A. BAUOMY, ESAM M. AL-SHAEBI \& SALEH AL-QURAISHY
}

\begin{abstract}
Cadmium, present in the environment, accumulates in different organs of animals and humans, and has deleterious effects on the kidney. In this study, we investigated the protective effects of the methanolic extract of Pleurotus ostreatus in comparison with silymarin on renal function in cadmium-intoxicated rats for five days. Rats intraperitoneally injected with cadmium chloride $(1 \mathrm{mg} / \mathrm{kg})$. These rats were treated with either P. ostreatus extract $(200 \mathrm{mg} / \mathrm{kg}$ ) or silymarin to investigate the protective effects of the extract. Cadmium treatment induced significant histopathological impairments and increased cadmium levels, DNA fragmentation, and renal oxidative stress. However, treatment with P. ostreatus extract or silymarin improved the pathology, reduced the level of cadmium in renal tissue, and restored DNA fragmentation. In addition, a significant reduction in lipid peroxidation and reactive oxygen species levels, and a significant increase in the levels of glutathione and catalase activity were observed. Thus, protective effects of $P$. ostreatus extract to its components. Chromatographic analysis of the P. ostreatus confirmed the presence of five phenolics (gallic acid, chlorogenic acid, catechin, propyl gallate, and cinnamic acid) that exhibit strong antioxidant properties as free radical scavengers. Therefore, our findings demonstrate that treatment with $P$. ostreatus extract protects against cadmium-induced nephrotoxicity in female rats.
\end{abstract}

Key words: cadmium, Pleurotus ostreatus, Kidney, Rats.

\section{INTRODUCTION}

Cadmium (Cd) is a highly toxic heavy metal (Yang \& Shu 2015), with unknown beneficial biological function in humans or animals. Cd is not normally found in body fluids or tissues; therefore, the presence of $\mathrm{Cd}$ in animals or humans is suggestive of environmental exposure (Alkushi et al. 2018). Cd is capable of entering the food chain; thus, it is considered a deleterious environmental pollutant, because it threatens both animal and human health (Katole et al. 2013) and has a very long biological half-life (about 30 years) in humans, especially in the kidneys. Cd bound to proteins, like sulfhydrylcontaining molecules, may cause nephropathy due to heavy metal accumulation. In addition, $\mathrm{Cd}$ toxicity stimulates the induction of oxidative stress in different organs (Morales et al. 2006), and chronic toxicity due to $\mathrm{Cd}$ causes renal proximal tubular dysfunction (Koçak \& Akçil 2006).

Silymarin (SIL) is an extract of the seeds of Silybum marianum (also known as milk thistle), a plant belonging to the family Asteraceae and has been used for its medicinal properties for several centuries (Basiglio et al. 2009). SIL has antioxidant, anti-inflammatory, anti-allergic, 
and anti-hyperglycemic properties (Pradhan \& Girish 2006). According to Rafieian-Kopaie \& Nasri (2012), SIL may be important for the maintenance of a healthy kidney and liver, and Ghosh et al. (2016) reported that SIL has a beneficial role in the pathophysiology of the mouse kidney.

Pleurotus ostreatus is a widely cultivated edible mushroom that exerts a wide range of pharmacological properties, including immunomodulatory (Jesenak et al. 2013), antitumor (Kong et al. 2014), and antioxidant (Ogbomida et al. 2018) properties. According to Zhu et al. (2019), P. ostreatus revealed hepatoprotective effects on $\mathrm{CCl}_{4}$-induced toxicity in rats. Moreover, Bindhu \& Das (2018) showed that $P$. ostreatus extract ameliorated the cognitive impairment and oxidative stress in Diabetic mellitus.

Therefore, the main goal of this study was to investigate the beneficial effects of $P$. ostreatus in comparison with SIL on renal function in response to $\mathrm{Cd}$-intoxication.

\section{MATERIALS AND METHODS}

\section{Chemicals and chromatographic analysis of POE}

Anhydrous cadmium chloride $\left(\mathrm{CdCl}_{2}\right)$ of analytical grade, CAS number 10108-64-2, was obtained from Sigma-Aldrich Chemical Co. (St. Louis, MO, USA). Silymarin (SIL) tablets (South Egypt Drug Industries"SEDICO", $6^{\text {th }}$ of October City, Egypt) were purchased from local pharmacies in Cairo, Egypt. P. ostreatus methanolic extract (POE) was prepared using the dried and homogenized fruiting bodies of P. ostreatus (50 g) that were purchased from the Agriculture Research Center, Cairo, Egypt. The metabolites were extracted using a constant ratio of 2:2:1 of methanol: chloroform: distilled water (Kim et al. 2010). The hydrophilic upper layer was removed from the extract and dried under vacuum for $24 \mathrm{~h}$.

According to Roberts et al. (2018), high performance liquid chromatography (HPLC) analysis for POE was performed using an Agilent 1260 series (Agilent, Santa Clara, CA, USA).

\section{Animals and experimental design}

Thirty female albino rats weighing 200-250 g (1012 weeks old) were purchased from the Holding Company for Biological Products and Vaccines (VACSERA, Cairo, Egypt).

To investigate the protective effects of $\mathrm{POE}$ on $\mathrm{Cd}$-induced renal toxicity, all rats were divided into five groups (nine rats per group). Group 1 (control) was intraperitoneally (i.p.) injected with saline and served as the control group. Group 2 (POE) was treated with POE only; rats received a dose of POE at $200 \mathrm{mg} / \mathrm{kg}$ body weight (b.wt.). Group 3 (untreated Cd-intoxicated) was orally administered saline, and only $\mathrm{CdCl}_{2}(1 \mathrm{mg} / \mathrm{kg}$ b.wt.) was injected i.p. after $1 \mathrm{~h}$ (Kataranovski et al. 2009). This dose did not cause any mortality in Cd-inoculated rats. Group 4 (POE-treated Cdintoxicated) was orally administered POE (200 $\mathrm{mg} / \mathrm{kg}$ b.wt.), and $\mathrm{CdCl}_{2}$ was i.p. injected after 1 h. Group 5 (SIL-treated Cd-intoxicated) was orally treated with SIL (100 mg/kg b.wt.), and $\mathrm{CdCl}_{2}$ was i.p. injected after $1 \mathrm{~h}$. All treatments were performed for five consecutive days. All rats were sacrificed by decapitation on day 6 post treatment. This study was approved by state authorities in accordance with the ethical committee for animal protection of National Organization for Drug Control and Research, Egypt (approval no: NODCAR/ II/18/19).

\section{Histopathology}

Formalin-fixed kidneys were embedded in paraffin, and $6 \mu \mathrm{m}$ sections were stained with hematoxylin and eosin. Histological damage was scored as follows: 0: absent; +: mild; ++: 
moderate; and +++: severe (Drury \& Wallington 1980).

\section{Cd level in renal homogenate}

The $\mathrm{Cd}$ ions in renal tissue homogenates were estimated using the protocol published by Murphy (Murphy 1987).

\section{DNA fragmentation assay}

According to Aljanabi \& Martinez (1997), DNA was extracted using the methods and data published by Wlodek et al. (1991) where a DNA ladder was used to determine the size of the apoptotic DNA fragments.

\section{Oxidative/anti-oxidative biomarkers}

The kidneys were homogenized in ice-cold Tris$\mathrm{HCl}(50 \mathrm{mM})$ and $300 \mathrm{mM}$ sucrose, ( $\mathrm{pH}$ 7.4) to produce a $50 \%(\mathrm{w} / \mathrm{v})$ homogenate (Tsakiris et al. 2004). The renal homogenate was centrifuged at $600 \times \mathrm{g}$ for $10 \mathrm{~min}$ and the supernatant was separated.

Glutathione (GSH) level in renal homogenates was measured according to Ellman (1959). The catalase (CAT) activity was measured according to Aebi (1984). Using previously published methods by Ohkawa et al. (1979), malondialdehyde (MDA) level was determined. To measure ROS production, nitro blue tetrazolium (NBT) was converted into for mazan by superoxide anion (Vrablic et al. 2001).

\section{Statistical analysis}

The data are expressed as means \pm standard error. In addition, the statistical (SPSS version 17.0) package program was used to perform oneway ANOVA. $P \leq 0.05$ is considered statistically significant.

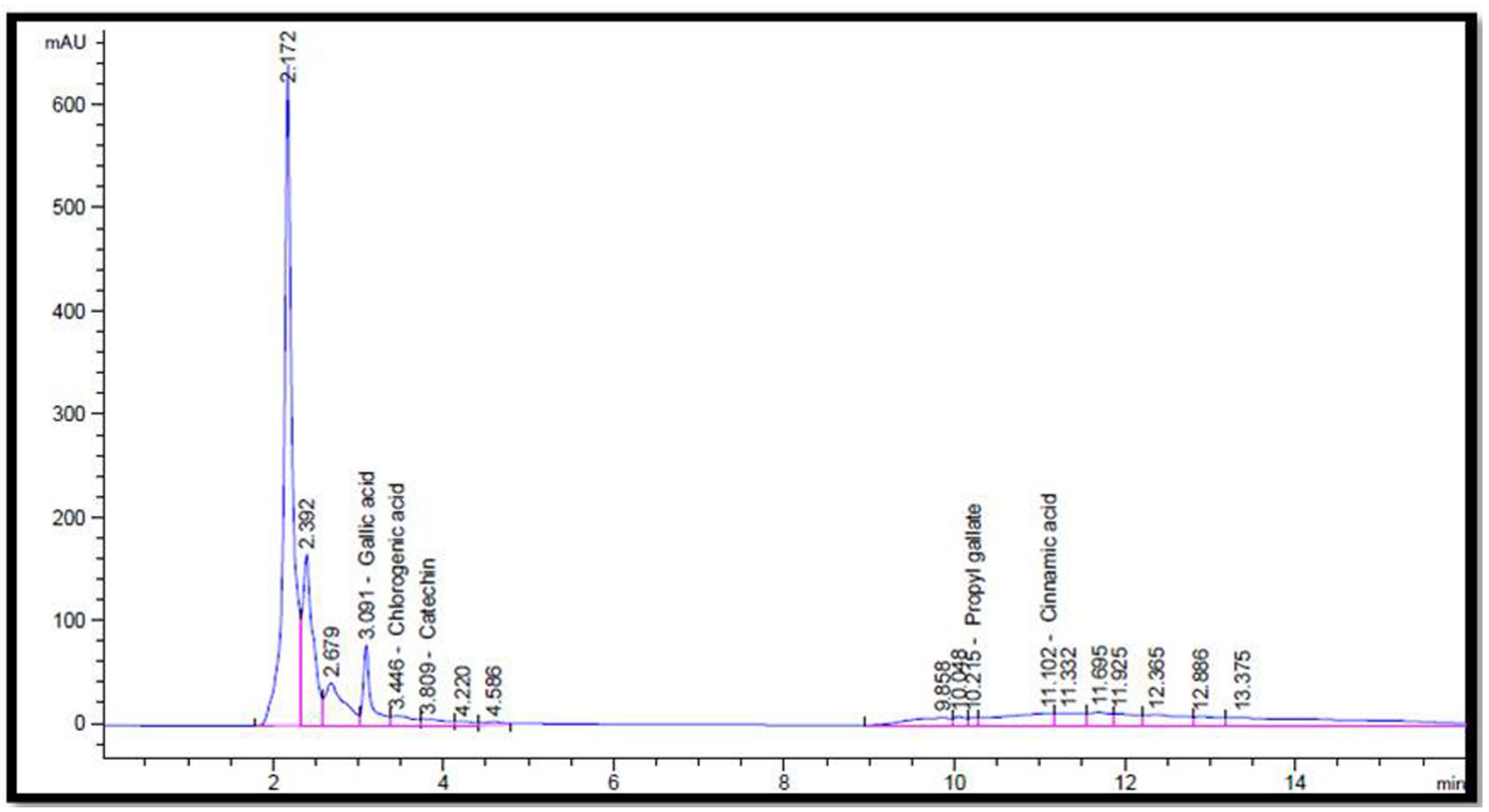

Figure 1. HPLC chromatogram recorded at $280 \mathrm{~nm}$ of a methanolic extract of P. ostreatus (POE). Only peaks corresponding to phenolic compounds or related compounds are indicated: gallic acid, chlorogenic acid, catechin, propyl gallate, and cinnamic acid. 


\section{RESULTS}

As shown in Figure (1), a representative chromatogram of POE, five phenolics and related compounds (gallic acid, chlorogenic acid, catechin, propyl gallate, and cinnamic acid) were positively identified and quantified in POE (Figure 1, Table SI- Supplementary Material). This was determined by comparing the chromatographic characteristics and absorption spectra with that of standard compounds.

$\mathrm{cd}$-intoxication resulted in a significant decrease in the renal index of rats compared to that of the control group (ratio of kidney weight (mg/rat) to body weight (g/rat)) (Figure 2). However, POE/SIL treatment significantly increased the renal index in $\mathrm{Cd}$-intoxicated rats relative to the $\mathrm{Cd}$ control group.

$\mathrm{cd}$ intoxication resulted in significant histological impairments in renal tissue. The glomerular tuft shrunk or was damaged; and cytoplasmic degeneration of renal tubules and pyknotic nuclei were observed. In addition, some tubules were necrotic and exhibited multiple foci of hemorrhage as well as dilatation and congestion of blood vessels (Figure 3 ).

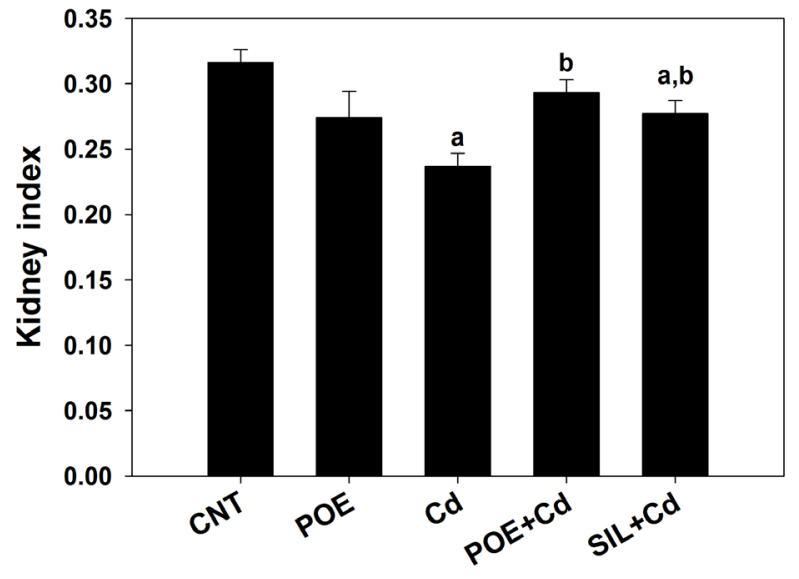

Figure 2. P. ostreatus methanolic extract (POE) and silymarin (SIL) treatment improved the kidney index of female albino rats in response to $\mathrm{Cd}$-intoxication. Values are presented as mean $\pm \mathrm{SE}$.

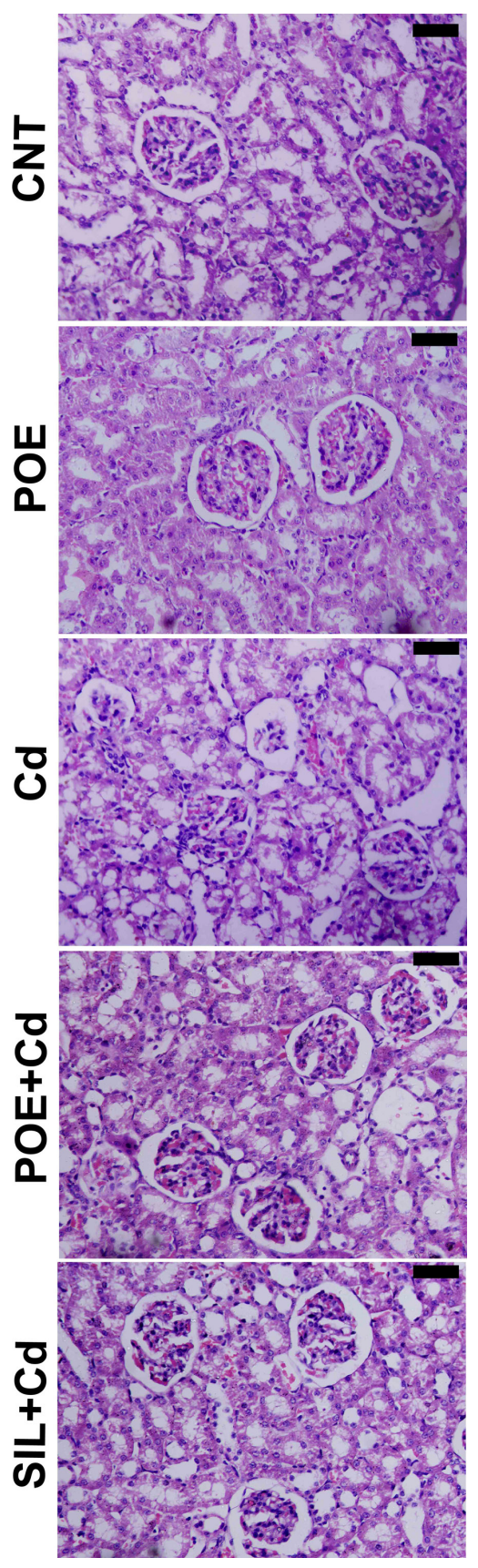

Figure 3. POE and SIL improved rat kidney damage induced by Cd. (CNT) Sections from control group with normal architecture. (POE) P. ostreatus methanolic extract inoculated group with normal structure. (Cd) Untreated Cd-intoxicated group with damaged glomeruli. $(\mathrm{POE}+\mathrm{Cd})$ Sections from P. ostreatus methanolic extract treated Cd-intoxicated female rats with improved histological structure. (SIL+Cd) Sections from silymarin-treatedCd-intoxicated rats with improved structure. Sections are stained with hematoxylin and eosin. Bar $=50 \mu \mathrm{m}$. 
Moreover, treatments with POE or SIL in the Cd-intoxicated rats significantly improved the histological picture (Figure 3). This is confirmed by the histological score of both groups of mice, recorded in Table I.

$\mathrm{Cd}$-intoxicated female rats had significantly elevated levels of renal $\mathrm{Cd}$ compared to that of the control group (Figure 4). Likewise, a significant increase in the $\mathrm{Cd}$ level was observed in groups 4 (POE-treated Cd-intoxicated rats) and 5 (SIL-treated Cd-intoxicated rats) relative to the control group. However, Cd levels significantly $(P<0.05)$ decreased in groups treated with POE before $\mathrm{Cd}$ injection. As with POE-treated rats, SIL treatment before $\mathrm{Cd}$-intoxication resulted in a significant decrease in renal $\mathrm{Cd}$ compared to that of the untreated $\mathrm{Cd}$-intoxicated group.

Cd-induced apoptotic DNA fragmentation in the kidneys of rats was determined by agarose gel electrophoresis and visualized by ethidium bromide fluorescence (Figure 5). No ladder was observed on the agarose gel in the DNA of normal kidney tissue (Figure 5), and no DNA laddering was detected in response to POE-only treatment, similar to the control group. Genomic DNA ladder formation was observed in the DNA of rats treated with $\mathrm{CdCl}_{2}(1 \mathrm{mg} / \mathrm{kg}$ b.wt.) (Figure 5). Treatment of $\mathrm{Cd}$-intoxicated rats with $\mathrm{POE}$ (Figure 5) restored the DNA laddering profile induced by the toxic effect of $\mathrm{CdCl}_{2}$ treatment, to normal. The degradation of DNA into oligonucleotide fragments was also observed in the $\mathrm{CdCl}_{2}$ group treated with SIL (Figure 5). These results suggest that POE was more effective than SIL in protecting against the nephrotoxic effect of $\mathrm{Cd}$-intoxication in female rats.

In addition, $C d$ induced a significant increase in MDA and ROS levels $(P \leq 0.05)$ in renal homogenates, whereas the level of nonenzymatic and enzymatic activity of antioxidants decreased significantly compared to those of the control group. Moreover, treatment of

Table I. P. ostreatus extract (POE) ameliorates histopathological kidney damages induced by cadmium.

\begin{tabular}{|c|c|c|c|c|}
\hline Group & \multicolumn{4}{|c|}{ Microscopic observation } \\
\hline & $\begin{array}{c}\text { Tubular } \\
\text { vacuolization }\end{array}$ & $\begin{array}{c}\text { Hydropic degeneration } \\
\text { change }\end{array}$ & Glomerular damage & $\begin{array}{c}\text { Inflammatory cellular } \\
\text { infiltration }\end{array}$ \\
\hline CNT & + & 0 & 0 & 0 \\
\hline POE & + & 0 & 0 & 0 \\
\hline Cd & +++ & ++ & +++ & ++ \\
\hline POE+Cd & + & + & + & + \\
\hline SIL+Cd & + & + & + & + \\
\hline
\end{tabular}

0: absent; +: mild; ++: moderate; +++; severe.

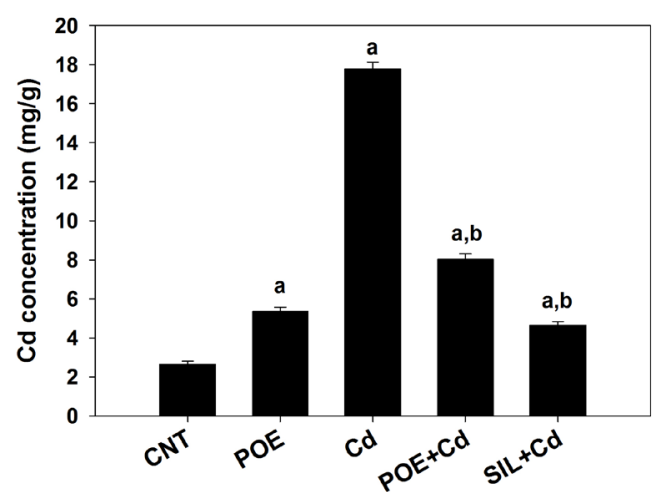

Figure 4. Mitigating effects of POE and SIL treatment on levels of renal $\mathrm{Cd}$ in $\mathrm{Cd}$-intoxicated rats. 


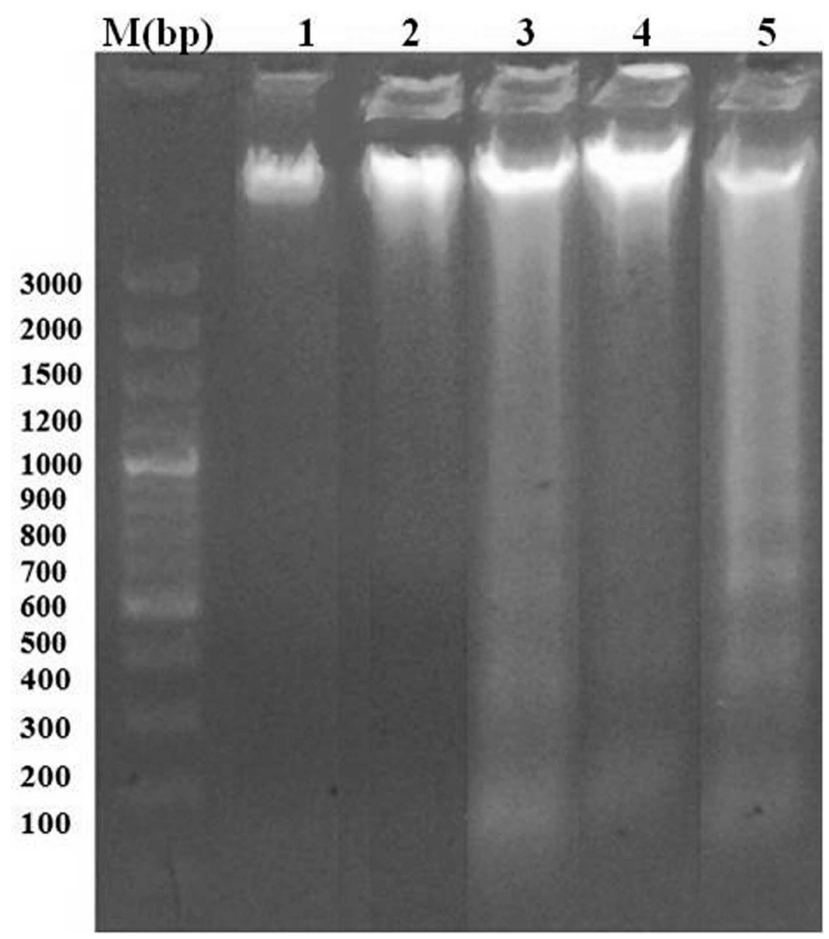

Figure 5. Effect of POE and SIL on DNA extracted from kidney tissue of normal and treated rats. Agarose gel electrophoresis photograph of M-Marker, lane 1: normal control group showed no DNA laddering, lane 2: POE-treated group showed no DNA laddering similar to control group, lane 3: $\mathrm{CdCl}_{2}$ treated group showed DNA laddering band, lane 4: $\mathrm{POE}+\mathrm{CdCl}_{2}$ treated group restored DNA laddering, and lane 5: $\mathrm{SIL}+\mathrm{CdCl}_{2}$ treated group showed DNA laddering profile of the $\mathrm{CdCl}_{2}-$ induced nephrotoxicity.

Table II. Effect of $P$. ostreatus methanolic extract (POE) / SIL on glutathione (GSH) level, catalase (CAT) activity, malondialdehyde level (MDA) and reactive oxygen species (ROS) level in renal tissue of Cd-intoxicated female rats.

\begin{tabular}{|c|c|c|c|c|}
\hline Groups & GSH (mg/g.tissue) & $\begin{array}{c}\text { CAT } \\
(\mathbf{U} / \mathbf{g})\end{array}$ & $\begin{array}{c}\text { MDA } \\
\text { (nmol/g tissue) }\end{array}$ & $\begin{array}{c}\text { ROS } \\
\text { ( } \boldsymbol{\mu m o l} / \mathbf{g} \text { tissue) }\end{array}$ \\
\hline CNT & $67.63 \pm 2.75$ & $1.47 \pm 0.06$ & $59.07 \pm 2.57$ & $1190 \pm 47.71$ \\
\hline POE & $71.04 \pm 1.71^{\mathrm{a}}$ & $1.63 \pm 0.05^{\mathrm{a}}$ & $47.64 \pm 2.00^{\mathrm{a}}$ & $1063 \pm 45.51$ \\
\hline Cd & $52.54 \pm 2.02^{\mathrm{a}}$ & $1.27 \pm 0.02^{\mathrm{a}}$ & $77.91 \pm 1.43^{\mathrm{a}}$ & $1525 \pm 45.51^{\mathrm{a}}$ \\
\hline POE+Cd & $62.49 \pm 1.59^{\mathrm{b}}$ & $1.42 \pm 0.02^{\mathrm{b}}$ & $71.88 \pm 1.76^{\mathrm{ab}}$ & $1200 \pm 25.04^{\mathrm{b}}$ \\
\hline SIL+Cd & $58.67 \pm 2.38^{\mathrm{a}}$ & $1.47 \pm 0.04^{\mathrm{b}}$ & $71.35 \pm 1.77^{\mathrm{ab}}$ & $1216 \pm 41.12^{\mathrm{b}}$ \\
\hline
\end{tabular}

Values are means \pm SE. a: Significant against control group (CNT) at $P \leq 0.05$, b: Significant against Cd group at $P \leq 0.05, n=6$.

Cd-intoxicated rats with SIL significantly reduced renal MDA and ROS levels; however, a significant increase was observed in CAT activity, and the increase observed in the level of GSH was not significant. Similarly, POE treatment significantly decreased renal MDA and ROS levels, $P \leq 0.05$; and significantly increased CAT activity and GSH levels relative to those of the untreated $\mathrm{Cd}$ intoxicated group (Table II).

\section{DISCUSSION}

The components of POE were identified as catechin, chlorogenic acid, gallic acid, propyl gallate, and cinnamic acid by HPLC. Burnett \& Levy (2012) reported that catechin is a potent antioxidant that inhibits the production of MDA in response to $\mathrm{Cd}$ toxicity in vitro and in vivo. In addition, Suzuki et al. (2006) found 
that chlorogenic acid is a strong polyphenolic antioxidant capable of scavenging free radicals. Chlorogenic acid inhibits Cd-mediated lipid peroxidation and reduces the utilization of non-enzymatic antioxidants, which improves the levels of GSH in brain tissue (Hao et al. 2015). Propyl gallate is extensively used as an antioxidant (Pop et al. 2013), and cinnamic acid exhibits antioxidant and free radical scavenging properties (Heim et al. 2002). SIL is also a strong antioxidant that may minimize the risks associated with free radical exposure (MDA, ROS) in the kidney (Tunca et al. 2009).

In our study, histological analysis revealed significant renal impairments in response to $\mathrm{Cd}$ intoxication. These results are in agreement with those of previous studies (Adi et al. 2016, Wongmekiat et al. 2018). In addition, Rafati et al. (2015) reported that $\mathrm{Cd}$-induced glomeruli structural changes, increases in the mesangial matrix, and swelling of the glomeruli with wider urinary spaces were detected. Cd treatment resulted in tubular dysfunction and nuclear membrane damage in glomerular epithelial cells of rats (Adi et al. 2016). However, Gobe \& Crane (2010) attributed the relationship between Cd-intoxication and renal cell injury to the sensitivity of the proximal tubular epithelium to oxidative stress. Similarly, Nazima et al. (2015) reported that increased nitric oxide and ROS generation is related to renal injury and induces the progression to renal failure.

Cinnamic, gallic, and chlorogenic acids maintain the normal architecture of the glomerulus and their antioxidant properties protect the kidneys of rats from nephrotoxicity (Yousuf \& Vellaichamy 2015). Moreover, Wongmekiat et al. (2018) suggested that catechin effectively protects renal tissue from $\mathrm{Cd}$ nephrotoxicity, and propyl gallate in rats is therapeutic in response to diabetic glomerular endothelial proliferation (Tian et al. 2012).
Abouzeinab (2015) concluded that SIL antioxidant activity can directly protect cells by stabilizing the permeability of the cellular membrane.

Treatment with POE or SIL significantly decreased the levels of $\mathrm{Cd}$ compared to that of the untreated $\mathrm{Cd}$-intoxicated rats. This result corresponds with the findings of Orr \& Bridges (2017) who observed that after chronic Cd exposure, approximately $50 \%$ of the total $\mathrm{Cd}$ accumulates in renal tissue. Cd enters the epithelium of the kidney via several different mechanisms. As a result, transport of $\mathrm{Cd}$ into renal tissue may require different channels and transporters $\left(\mathrm{Ca}^{2+}, \mathrm{Fe}^{2+}\right.$, and $\left.\mathrm{Zn}^{2+}\right)$, or the formation of complexes with sulfhydryl (thiol)containing biomolecules, such as GSH (Lee \& Yu 2016). Moreover, these $\mathrm{Cd}$-thiol complexes could penetrate the cells and regulate the transfer of some organic compounds (Ganger et al. 2016).

In this study, $\mathrm{CdCl}_{2}$ induced apoptotic DNA fragmentation in the kidney while POE or SIL was able to reduce these changes. Rana et al. (2018) reported that $\mathrm{CdCl}_{2}$ induces DNA fragmentation and apoptotic cell death in different types of cells due to its ability to induce the oxidative stress.

Treatment with chlorogenic, gallic, and cinnamic acids prevents oxidative DNA damage in experimental animals (Cheng et al. 2007). Moreover, Rafieian-Kopaie \& Nasri (2012) showed that SIL accumulates in renal cells and aids in tissue repair and regeneration, by elevating the synthesis of proteins and nucleic acids.

Adi et al. (2016) suggested that exposure to $\mathrm{Cd}$ alters the metabolism of antioxidants and induces oxidative stress, generating free radicals and CAT activity and reducing other enzymatic antioxidants. In addition, ROS is involved in the deleterious effects of $\mathrm{Cd}$-intoxication on human health. ROS accumulates in injured renal tissues and disturbs the balance of enzymatic and nonenzymatic antioxidant agents in cells. 
After Cd absorption, ROS binds to metallothionein and enters the injured renal space via the glomerulus, forming the metallothionein-cd complex. The formed complex is degraded by lysosomes of the renal proximal tubules, causing $\mathrm{Cd}$ release. Consequently, research related to recovery of the antioxidant levels after Cd toxicity is of major significance (Rana et al. 2018).

POE has potential antioxidant activity that inhibits GSH oxidation and protects related enzymes during aging (Jayakumar et al. 2010). Bindhu \& Das (2018) also concluded that POE treatment inhibited MDA formation, raised GSH levels, and increased antioxidant enzyme activity (CAT).

Collectively, our findings provide evidence that $\mathrm{POE}$ protect against $\mathrm{Cd}$ nephrotoxicity in rats. The administration of POE to $\mathrm{Cd}$-intoxicated rats improved the damaged renal architecture that resulted in $\mathrm{CdCl}_{2}$ treatment. In addition, the level of $\mathrm{Cd}$ and DNA fragmentation were decreased. The POE treatment balanced the level of non-enzymatic and enzymatic antioxidants in $\mathrm{Cd}$ administered rats. We referred these improvements to the phenolic constituents of POE. However, further studies are required to understand the exact mechanisms responsible for protection.

\section{Acknowledgments}

This study was supported by Research Supporting Project (RSP-2019/23), King Saud University.

\section{REFERENCES}

ABOUZEINAB NS. 2015. Antioxidant effect of silymarin on cisplatin-induced renal oxidative stress in rats. J Pharmacol Toxicol 10(1): 1-19.

ADI PJ, BURRA SP, VATAPARTI AR \& MATCHA B. 2016. Calcium, zinc and vitamin E ameliorate cadmium-induced renal oxidative damage in albino Wistar rats. Toxicol Rep 3: 591-597.
AEBI H. 1984. Catalase in vitro. In: Methods in Enzymology 105: 121-126.

ALJANABI SM \& MARTINEZ I. 1997. Universal and rapid saltextraction of high quality genomic DNA for PCR-based techniques. Nucl Acids Res 25(22): 4692-4693.

ALKUSHI AG, SINNA MM, EL-HADY M \& ELSAWY NA. 2018. Structural Changes in Adult Rat Liver Following Cadmium Treatment. Pak J Nut 17(2): 89-101.

BASIGLIO CL, SÁNCHEZ POZZI EJ, MOTTINO AD \& ROMA MG. 2009. Differential effects of silymarin and its active component silibinin on plasma membrane stability and hepatocellular lysis. Chemico-Biol Interact 179(2-3): 297-303.

BINDHU J \& DAS A. 2018. Evaluation of Edible Oyster Mushroom (Pleurotusostreatus) on Oxidative Stress and Neurological Cognitive Disorder in Streptozotocin Diabetic Rats. J Clin Invest 8(1): 43-52.

BURNETT BP \& LEVY RM. 2012. 5-Lipoxygenase metabolic contributions to NSAID-induced organ toxicity. Advan Ther 29(2): 79-98.

CHENG JC, DAI F, ZHOU B, YANG L \& LIU ZL. 2007. Antioxidant activity of hydroxyl cinnamic acid derivatives in human low density lipoprotein: mechanism and structureactivity relationship. Food Chem 104(1): 132-139.

DRURY RA \& WALLINGTON EA. 1980. Carleton's histological technique. $5^{\text {th }}$ ed., Oxford University Press, Oxford, New York, Toronto, 188-291.

ELLMAN GL. 1959. Tissue sulfhydryl groups. Arch Biochem Bioph 82(1): 70-77.

EMINZADE S, URAS F \& IZZETTIN FV. 2008. Silymarin protects liver against toxic effects of anti-tuberculosis drugs in experimental animals. Nut Metabol 5: 18.

GANGER R, GARLA R, MOHANTY BP, BANSAL MP \& GARG ML. 2016. Protective Effects of Zinc Against Acute Arsenic Toxicity by Regulating Antioxidant Defense System and Cumulative Metallothionein Expression. Biol Trace Elem Res 169(2): 218-229.

GHOSH S, SARKARA, BHATTACHARYYA S \& SIL PC. 2016. Silymarin Protects Mouse Liver and Kidney from Thioacetamide Induced Toxicity by Scavenging Reactive Oxygen Species and Activating PI3K-Akt Pathway. Front Pharmacol 7(481): 1-15.

GOBE G \& CRANE D. 2010. Mitochondria, reactive oxygen species and cadmium toxicity in the kidney. Toxicol Let 198(1): 49-55.

HAO ML, PAN N, ZHANG QH \& WANG XH. 2015. Therapeutic efficacy of chlorogenic acid on cadmium-induced 
oxidative neuropathy in a murine model. Exper Therap Med 9(5): 1887-1894.

HEIM KE, TAGLIAFERRO AR \& BOBILYA DJ. 2002. Flavonoid antioxidants: chemistry, metabolism and structureactivity relationships. J Nutr Biochem 13(10): 572-584.

JAYAKUMAR T, RAMESH E \& GERALDINE P. 2006. Antioxidant activity of the oyster mushroom, Pleurotus ostreatus, on $\mathrm{CCl}_{4}$-induced liver injury in rats. Food Chem Toxicol 44(12): 1989-1996.

JAYAKUMAR T, THOMAS PA, RAMESH E \& GERALDINE P. 2010. An extract of the Pleurotus ostreatus mushroom bolsters the glutathione redox system in various organs of aged rats. J Med Food 13(4): 771-778.

JESENAK M, MAJTAN J, RENNEROVA Z, KYSELOVIC J, BANOVCIN $P$ \& HRUBISKO M. 2013. Immunomodulatory effect of pleuran ( $\beta$-glucan from Pleurotus ostreatus) in children with recurrent respiratory tract infections. Int Immunopharmacol 15(2): 395-399.

KATARANOVSKI M, MIRKOV I, BELIJ S, NIKOLIC M, ZOLOTAREVSKI L, CIRIC D \& KATARANOVSKI D. 2009. Lungs: Remote inflammatory target of systemic cadmium administration in rats. Environmen Toxicol Pharmacol 28(2): 225-231.

KATOLE SB, KUMAR P \& PATIL RD. 2013. Environmental pollutants and livestock health: a review. Vet Res Int 1(1): $1-13$.

KIM HK, CHOI YH \& VERPOORTE R. 2010. NMR-based metabolomics analysis of plants. Nature Prot 5(3): 536-549.

KOÇAK M \& AKÇIL E. 2006. The effects of chronic cadmium toxicity on the hemostatic system. Pathophysiol Haemos Thromb 35(6): 411-416.

KONG FE, LI FE, HE Z, JIANG Y, HAO R, SUN X \& TONG H. 2014. Antitumor and macrophage activation induced by alkaliextracted polysaccharide from Pleurotus ostreatus. Int J Biolo Macromol 69: 561-566.

LEE CH \& YU HS. 2016. Role of mitochondria, ROS, and DNA damage in arsenic induced carcinogenesis. Front Biosci 8: $312-320$.

MORALES AI, VICENTE-SÁNCHEZ C, SANDOVAL JM, EGIDO J, MAYORAL P, ARÉVALO MA, FERNÁNDEZ-TAGARRO M, LÓPEZNOVOA JM \& PÉREZ-BARRIOCANAL F. 2006. Protective effect of quercetin on experimental chronic cadmium nephrotoxicity in rats is based on its antioxidant properties. Food Chem Toxicol 44(12): 2092-2100.

MURPHY VA. 1987. Method for determination of sodium, potassium, calcium, magnesium, chloride and phosphate in the rat choroid plexus by flame atomic absorption and visible spectroscopy. Analyt Biochem 161: 144-151.

NAZIMA B, MANOHARAN V \& MILTONPRABU S. 2015. Grape seed proanthocyanidins ameliorates cadmium-induced renal injury and oxidative stress in experimental rats through the up-regulation of nuclear related factor 2 and antioxidant responsive elements. Biochem Cell Biol 93(3): 210-226.

OGBOMIDA ET, OMOFONMWAN K, AGANMWONYI I, FASIPE IP, ENUNEKU A \& EZEMONYE LIN. 2018. Bioactive profiling and therapeutic potential of mushroom (Pleurotus tuberregium) extract on Wistar albino rats (Ratus norvegicus) exposed to arsenic and chromium toxicity. Toxicol Rep 5: 401-410.

OHKAWA H, OHISHI N \& YAGI K. 1979. Assay for lipid peroxides in animal tissues by thiobarbituric acid reaction. Anal Biochem 95(2): 351-358.

ORR SE \& BRIDGES CC. 2017. Chronic Kidney Disease and Exposure to Nephrotoxic Metals. Int J Molecul Sci 18(5): 1039.

POP A, BERCE C, BOLFA P, NAGY A, CATOI C, DUMITRESCU I, SILAGHI-DUMITRESCU L \& LOGHIN F. 2013. Evaluation of the possible endocrine disruptive effect of butylated hydroxyl anisole, butylated hydroxyl toluene and propyl gallate in immature female rats. FARMACIA 61(1): 202-211.

PRADHAN SC \& GIRISH C. 2006. Hepatoprotective herbal drug, silymarin from experimental pharmacology to clinical medicine. Ind J Med Res 124(5): 491-504.

RAFATI A, HOSEINI L, BABAI A, NOORAFSHAN A, HAGHBIN H \& KARBALAY-DOUST S. 2015. Mitigating effect of resveratrol on the structural changes of mice liver and kidney induced by cadmium; a stereological study. Prev Nutr Food Sci 20(4): 266-275.

RAFIEIAN-KOPAIE M \& NASRI H. 2012. Silymarin and diabetic nephropathy. J Renal Inj Prev 1(1): 3-5.

RANA K, VERMA Y, RANI V \& RANA SVS. 2018. Renal toxicity of nanoparticles of cadmium sulphide in rat. Chemosph 193: $142-150$

ROBERTS CE, RANER GM \& ISAACS GD. 2018. High Performance Liquid Chromatography Separation of Epigenetic Cytosine Variants. Methods Protoc 1(2): 10.

SUZUKI A, YAMAMOTO N, JOKURA H, YAMAMOTO M, FUJII A, TOKIMITSU I \& SAITO I. 2006. Chlorogenic acid attenuates hypertension and improves endothelial function in spontaneously hypertensive rats. J Hyperten 24(6): 1065-1073. 
TIAN S, TANG J, LIU H, WANG L, SHEN J, LI J \& GAN Y. 2012. Propyl Gallate Plays a Nephroprotective Role in Early Stage of Diabetic Nephropathy Associated with Suppression of Glomerular Endothelial Cell Proliferation and Angiogenesis. Exp Diab Res 2012: 1-8.

TSAKIRIS S, SCHULPIS KH, MARINOU K \& BEHRAKIS P. 2004. Protective effect of L-cysteine and glutathione on the modulated suckling rat brain $\mathrm{Na}^{+}, \mathrm{K}^{+}$-ATPase and $\mathrm{Mg}^{2+}-$ ATPase activities induced by the in vitro galactosaemia. Pharmacol Res 49(5): 475-479.

TUNCA R, SOZMEN M, CITIL M, KARAPEHLIVAN M, ERGINSOY S \& YAPAR K. 2009. Pyridine induction of cytochrome P450$1 A 1$, iNOS and metallothionein in Syrian hamsters and protective effects of silymarin. Exp Toxicol Pathol 61(3): 243-255.

VRABLIC AS, ALBRIGHT CD, CRACIUNESCU CN, SALGANIK RI \& ZEISEL SH. 2001. Altered mitochondrial function and over generation of reactive oxygen species precede the induction of apoptosis by 1-0-octadecyl-2-methyl-racglycero-3-phosphocholine in p53-defective hepatocytes. FASEB J 15(10): 1739-1744.

WLODEK D, BANATH J \& OLIVE PL. 1991. Comparison between pulsed-field and constant-field gel electrophoresis for measurement of DNA double-strand breaks in irradiated Chinese hamster ovary cells. Int J Rad Biol 60(5): 779-790.

WONGMEKIAT O, PEERAPANYASUT W \& KOBROOB A. 2018. Catechin supplementation prevents kidney damage in rats repeatedly exposed to cadmium through mitochondrial protection. Naunyn-Schmiedeberg's Arch Pharmacol 391(4): 385-394.

YANG H \& SHU Y. 2015. Cadmium transporters in the kidney and cadmium-induced nephrotoxicity. Int J Mol Sci 16(1): 1484-1494.

YOUSUF MJ \& VELLAICHAMY E. 2015. Protective activity of gallic acid against glyoxal-induced renal fibrosis in experimental rats. Toxicol Rep 2: 1246-1254.

ZHU B, LI Y, HU T \& ZHANG Y. 2019. The hepatoprotective effect of polysaccharides from Pleurotus ostreatus on carbon tetrachloride-induced acute liver injury rats. Int J Biol Macromol 15(131): 1-9.

\section{SUPPLEMENTARY MATERIAL}

Table SI.

\section{How to cite}

DKHIL MA, DIAB MSM, LOKMAN MS, EL-SAYED H, BAUOMY AA, AL-SHAEBI
EM \& AL-QURAISHY S. 2020. Nephroprotective effect of Pleurotus ostreatus extract against cadmium chloride toxicity in rats. An Acad Bras Cienc 92: e20191121. DOI 10.1590/0001-3765202020191121.

Manuscript received on September 17, 2019, accepted for publication on November 7, 2019

\section{MOHAMED A. DKHIL ${ }^{1,2}$}

https://orcid.org/0000-0003-1869-5800

MARWA S.M. DIAB ${ }^{3}$

https://orcid.org/0000-0001-7793-5507

\section{MAHA S. LOKMAN ${ }^{2}$}

https://orcid.org/0000-0003-2830-3479

HEBA EL-SAYED ${ }^{4}$

https://orcid.org/0000-0003-2962-6755

AMIRA A. BAUOMY²

https://orcid.org/0000-0002-0856-3057

ESAM M. AL-SHAEBI ${ }^{1}$

https://orcid.org/0000-0003-1614-4802

\section{SALEH AL-QURAISHY ${ }^{1}$}

https://orcid.org/0000-0003-4204-3124

${ }^{1}$ Department of Zoology, College of Science, King

Saud University, 11451 Riyadh, Saudi Arabia

${ }^{2}$ Department of Zoology and Entomology, Faculty of Science, Helwan University, 11795 Helwan, Ain Helwan, Cairo, Egypt

${ }^{3}$ Molecular Drug Evaluation Department, National Organization for Drug Control \& Research/ NODCAR, 12535 Giza, Egypt

${ }^{4}$ Botany and Microbiology Department, Faculty of Science, Helwan University, 11795 Helwan, Ain Helwan, Cairo, Egypt

Correspondence to: MOHAMED A. DKHIL

E-mail:mohameddkhil@yahoo.com

\section{Author contributions}

MAD, MSMD, SA and AAB designed the study and critically revised the manuscript. MSMD, AAB, MSL, HE, EMA and SA contributed to the main experiment. All authors read and approved the final manuscript.

\section{(c) $B Y$}

